\title{
Social class and sex as determinants of future orientation (time perspective) in adults*
}

\author{
ROLF W. SCHMIDT \\ HELMUT LAMM \\ GISELA TROMMSDORFF \\ Universität Mannheim
}

\section{Abstract}

This study was designed to test hypotheses concerning the influence of sex roles and social status on future orientation (FO). The latter was measured in various categories (spheres of life), on the dimensions of density (number of hopes and fears cited by the subject), extension, and optimism-pessimism. Also included was a measure of 'internal vs. external control' (the subject's assessment as to whether the realization of his hopes and fears is dependent more on himself or more on external factors). Subjects were 100 employed men and women of the lower and middle class. It was found that, in comparison with women, men voiced more hopes/fears in the public sphere (economy, politics, environment) and fewer in the private sphere (family, occupation, personal development). Men had a more extended FO in the occupational and economic spheres; women, in contrast, in the private sphere. (These results contradicted the assumption of earlier studies that FO is a general orientation. not varying across different domains of life.) Middle-class (in comparison to lowerclass) persons manifested a more extended FO, envisioned the distant future more optimistically, and believed more markedly that the realization of their hopes and fears depended on themselves.

\section{INTRODUCTION}

This paper offers a theoretical analysis of some determinants of future orientation (FO) and describes an empirical study designed to test some hypotheses derived from our theoretical analysis.

Future orientation is that part of time orientation which is directed toward the future (its other parts being past orientation and present orientation). FO here is defined as one's attitude toward the future. Thus, FO has a cognitive and an affectiveevaluative component. By the narrower term future time perspective (FTP) we will

\footnotetext{
*Research carried out at the Sonderforschungsbereich 24 (Sozial- und Wirtschaftspyschologische Entscheidungsforschung), Universität Mannheim, with funds from the Deutsche Forschungsgemeinschaft and with the support of the State of Bader-Württemberg. The three authors have contributed equally to this article. Requests for reprints should be sent to $\mathrm{H}$. Lamm.
} 
refer to the cognitive component (e.g., density and extension) of FO. There is a lot of confusion about the exact definiton of 'FTP' and 'FO' in the literature. Both terms are often used interchangeably. The proposal made here should help to clarify the relation between FTP and FO. (In the present article the narrower term FTP is employed only when referring to literature in which this term was used.)

One central point in this study is our rejection of the assumption of a general FO extending across all domains of life. According to this latter assumption, which is seldom made explicit, an individual's FO (and FTP) is of the same structure and has the same emotional tone in all domains of his life. Kasakos (1971) shows that this assumption is not unproblematic. Namely, one must ask the question if, for example, FO in regard to occupational education has the same consequences for behavioural decisions as in regard to freetime activities. Aside from this, it is probable that the emotional colouring of the $\mathrm{FO}$, for example the dependence upon experience of success or failure, varies among different life domains.

Frank (1939) had already called attention to the fact that a person can develop various types of time perspective which are directed in each case to different domains of life. However, this point has not been heeded by researchers for a long time. Not until recently did Lessing (1971) try to differentiate between a private and public FTP.

Quite possibly the contradictory results of experiments dealing with the connection between social class and FO may be due to the assumption of a generalized FO: In the works of LeShan (1952), Lessing (1968), Graves (1962), and Vincent (1965), a significant relationship between class membership (social status) and the extension of FTP was found, but Ellis et al. (1955) and Judson and Tuttle (1966) could not support this finding. Disregarding the fact that different methods of measurement were used in these studies, one can assume that the differences would not have arisen if FTP had been analyzed separately for different life domains.

\section{CONCEPT OF FUTURE ORIENTATION}

The number of articles concerning FO has rapidly increased in the last two decades, but the number of the methods of measurement has also grown correspondingly. However, as Ruiz, Reivich, and Krauss (1967) and recently Platt et al. (1971) pointed out, in a majority of the studies there was no significant correlation between different types of FO measurements.

One reason for the divergence of the different studies of FO probably is that most researchers approach their subject without a theoretical basis.

The field theory of Lewin (1948; 1951) is one of the few theories in social psychology which includes the subjective experience of time in the list of behaviour-determining variables. According to this theory an individual's behaviour is determined by the field that is actually present. This psychological field has a certain temporal 'depth'. It includes the psychological past, the psychological present, and the psychological future as far as they are a dimension of a given life environment at a given time (Lewin, 1951).

'Psychological future' is defined here as those future events which the individual anticipates, including those phenomena whose occurrence he hopes for, fears or expects.

By 'future orientation' (FO) we understand an individual's anticipation and assess- 
ment of all events which enter into his psychological future. This anticipation may occur on several dimensions: (a) content structuring (coherence and density), (b) time structuring (extension), and (c) an affective dimension (optimism-pessimism). More extensive analyses on future time perspective and future orientation can be found in Bergius (1957), Doob (1971), Fraisse (1957), Mönks (1967), Winnubst (1974), and Trommsdorff and Lamm (1975).

The kind of multidimensional concept of FO which is proposed here is used quite often in psychological literature (for example, Wallace, 1956; Kastenbaum, 196I; Klineberg, 1967; Kasakos, 1971; and Cottle and Klineberg, 1974). However, only a minority of researchers pursue this concept consistently in their empirical studies. Frequently, just one variable is investigated: the extension of $\mathrm{FO}^{\mathrm{l}}$. Some authors actually identify FO with its extension (for example LeShan, 1952; Barndt and Johnson, 1955; Teahan, 1958; Judson and Tuttle, 1966; and Barabasz, 1970). If FO is to function as a predicting variable, its multidimensional character must not be reduced to unidimensionality in empirical studies.

\section{THE DIMENSIONS OF FUTURE ORIENTATION}

The dimensions selected here are a sample from a greater 'population' of possible dimensions, aspects or correlates of future orientation (if the latter is conceptualized more broadly). Some of these are delay of gratification (see Mischel, 1974), rationality, cognitive complexity (see McGuire, 1967) and achievement motivation (see Heckhausen, 1967).

\section{Structure}

\section{(a) Coherence}

Wallace (1956) measures the structural aspect of FO by the variable of 'coherence' 'the degree of structural organization of the events in the future time span', p. 240). The subject has to name 10 future events and indicate for each the year of its probable occurrence. In a further experimental task, these same events are ranked according to their temporal order. The correlation coefficient between years of occurrence and place of rank serves as the score for coherence.

It must be said as an objection to the validity of this method that the subjects basically carry out the same process twice. Due to this, the high correlations which Wallace (1956) found are not at all surprising. They could be more a measure of the subjects' memory than a measure of the coherence of their $\mathrm{FO}^{2}$. Hence, these variables were not included in this study.

\section{(b) Density}

Kastenbaum (1961) introduced the variable of density and gave it the working definition of the number of events expected by the subject.

\footnotetext{
'It should be remembered here that 'extension' is a dimension of the classical FTP which we consider as a part of FO.

${ }^{2}$ Cf. the criticism by Bergius (1957, p. 63) and by Kasakos (1971, p. 42).
} 
By means of this operational definition Kastenbaum (1961) limited himself exclusively to the quantitative aspect of the variable and neglected a classification of their contents. However, as noted above, it is important for a behavioural prognosis to know on which domain of his life the subject has concentrated in his assessment of his future; the simple number of anticipated events is not sufficient information. Therefore, we have refined this variable by measuring it in different categories (domains of life). In this way it is easier to determine if a person is more concerned, for example with future developments in his occupational field or in his personal life, or whether he is mainly concerned with political processes.

\section{(c) Extension}

Wallace (1956, p. 240) defines extension as "the length of the future time span which is conceptualized' and operationalizes this variable as follows: '. . the range of years included between $S$ 's actual age and the most distant event given by him' (Wallace, 1956 , p. 241). ${ }^{3}$ The temporal extension of a FO is therefore indicated by the most extreme boundary ('the most distant event') of the future time span perceived and structured by the subject.

The assumption of a general FO (one extending uniformly across all domains of life) is implicit in Wallace's definition. Based upon the above-mentioned problems with such an assumption, the extension of $F O$ is measured separately for various domains of life in the present study so that intra-individual variation of future orientation can be taken into account.

\section{Optimism-pessimism}

Apart from a few exceptions (Teahan, 1958; Cantril, 1965; Lehr, 1968b; and Ornauer et al., 1974), the affective components of FO have received little attention in psychological literature. But whether a person is more or less future-oriented depends on the results of this emotional evaluation of his future. If he anticipates his future as a space in time where negatively valued occurrences prevail (pessimistic), this attitude could prevent an extension of FO in the more distant future. Teahan's (1958) finding of a positive correlation between optimism and extension of FO strengthens this hypothesis. He defined optimism as ' ... the hope that positive changes can be expected in the future ...' (p. 380).

Cantril (1965) and Ornauer et al. (1974) define optimism-pessimism as the difference between the individual's evaluation of the future and the present. In this measure, the subject must specify, on a 'self-anchoring scale', where he stands today in relation to the best conceivable life condition, where he stood five years ago, and where he will stand within five years.

In the present study we will use Cantril's version in a slightly modified form and define optimism as a positive difference between the evaluation of the future and the evaluation of the present, and pessimism as a negative difference between the two values. Again our variables are based on separate measurements for various domains of life.

${ }^{3}$ Klineberg (1967, p. 188 and 1968, p. 255) operationalized his terms 'sportaneous extension' correspondingly as 'the greatest distance into future'. 


\section{INTERNAL VS. EXTERNAL CONTROL}

The description of future events as determined by oneself versus by outside forces may be connected with the extension of FO and with optimism-pessimism. There are only a few - partly contradictory - empirical findings on this relationship (Jessor et al., 1968; and Tolor, Brannigan, and Murphy, 1970). However, it can be conjectured that the conviction that one himself can influence future events in specific spheres of life leads to an optimistic evaluation of the developments in that sphere. The positive correlation between optimism and 'internal control' reported by Gore and Rotter (1963) support this assumption.

'The I-E variable is defined as a generalized orientation or expectation that the outcomes of one's behaviour are contingent upon what one does (internal control) as opposed to being determined by outside forces, such as powerful others, or impersonal random forces, such as luck, fate or chance (external control)' (Jessor et al., 1968, p. 104). Building on this definition, the variables in the present study are operationalized through the subject's specifications as to whether the occurrence of an expected event is more contingent on himself or on luck, chance, etc.

\section{DERIVATION OF THE HYPOTHESES}

\section{(1) Social status}

\section{(a) Structure and extension of FO}

The results of various researchers (e.g., Rosen, 1956) show that social status and the availability of economic power influence the goal-settings (success motivation and extension of goals in the future), planning and structuring of future periods of time and the behavioural consequences of FO (such as the willingness to postpone rewards). ${ }^{4}$

For predicting a person's future behaviour it is important to know if he is in a position to anticipate distant events and to include them in his plan of behaviour. This ability to anticipate long-term consequences of action and to take them into consideration when making decisions concerning behaviour seems to be a significant basis for the process of social adaption. Persons inclined toward deviant behaviour can be characterized by a shortened FO (Cohen, 1955; Bandt and Johnson, 1955; Mönks, 1967; Jessor et al., 1968; and Stein et al., 1968). This relationship has also been found with maladapted children (Klineberg, 1967). LeShan (1952) found a shorter FO in lower-class than in upper-class children. ${ }^{5}$ Heckhausen $(1963 ; 1967)$ implied that middle-class children, along with their pronounced achievement motivation, also set longer-term goals than lower-class children. Grauer (1972b) argues that persons with greater achievement and success motivation are more apt to set long-term goals than less highly motivated persons because such goals are more challenging for them. Brim and Forer (1956) discovered in a US nation-wide official

\footnotetext{
${ }^{4}$ In the present study the behavioural consequences a re not taken into consideration.

'Even though several authors suggest that the ability to delay gratification is more pronounced in the middle class than in the lower class (Neidhardt, 1967; Mollenhauer, 1969; and Oevermann, 1969), few empirical studies of this have been carried out (Allen, 1970; and Mischel, 1974).
} 
survey that long-term planning for the future depended on the level of the social status of the adolescents questioned. ${ }^{6}$ However, a different view can be taken when considering the different range of options available to the two social groups in question. On this view, a shorter or longer time perspective (e.g., as evident in shorter or longer range planning) may reflect a realistic appraisal of future possibilities (see Miller, Riesman and Seagull, 1965).

Child-raising practices (e.g., Ewert, 1970; Neidhardt, 1967, 1968) and the conditions of secondary socialization in school and at work (Wurzbacher, 1966; Daheim, 1970a) for the lower classes are such that cognitive-intellectual disadvantages in language and motivational areas are established or sometimes strengthened, obviating the development of a structured, long-term FO. For the establishment of a structured FO and for effective behavioural planning it is necessary for the person to analytically structure the future and to process information pertaining to the ordering, causal interrelationships and effects of future events. Now, lower class people's relative economic and social powerlessness (see Lenski, 1966) and their language style ('restringent code') (see Bernstein, 1959; Hess and Shipman, 1965) are among the factors possibly contributing to the lesser extension of their $F O$ in unfamiliar domains of life (e.g., the public domain) and in unattractive domains (e.g., the job domain). However, one cannot draw the conclusion from the above remarks that lower-class persons are 'maladapted' concerning their FO. A longer extension of FO does not necessarily imply greater rationality, better social adjustment and greater delay capacity.

Though a dichotomization of social class might be construed as an unrealistic preconception involving class sterotyping, in this article we have rejected a (similarly unrealistic) three-fold classification into lower, middle and upper class.

Hypothesis $I$. Lower-class persons have a shorter $\mathrm{FO}$ than middle-class persons in most domains of their lives.

\section{(b) Causal attribution and optimism-pessimism}

The situation of persons in the lower class can be characterized as 'a reduction of possibilities of experience' (Knupfer, 1953); a situationally determined, reduced prospect of expanding this realm of experience, and thus a narrowing of the scope of probable future experience. Moreover, by realistic assessment of their present circumstances in relation to future possibilities, the members of the lower class, in comparison with members of other classes, anticipate less control by themselves of their future. Battle and Rotter (1963) found that lower-class school children in contrast to middle-class school children placed the responsibility for their living circumstances on external factors (fate, environment, etc.) instead of seeing themselves as responsible for them. Aside from that, children with internal attribution were surer of success than those with external attribution.

Due to this connection it could be concluded that persons with external attribution as opposed to those with internal attribution have a more pessimistic FO.

External attribution and pessimism about the future are presumably dependent upon the perceived possibilities of success, which result in turn from the condition of

-As far as planning behaviour can be found in the lower classes, it remains in the personal sphere (provision of means for existence) and has no further effect on occupational and other attempts at mobility (Grimm, 1966). 
the present social situation. The more minimal possibilities of success for the lower classes, in comparison with the broad spectrum of success possibilities for the middleclass members, must consequently determine the kind of attribution and the optimistic/pessimistic assessment of the future.

Such a relationship was actually shown in the study by Battle and Rotter (1963), which becomes even clearer by means of an investigation of a further social factor, that of race: black, middle-class school children shared the internal attribution of white middle-class school children while the black, lower-class, school children (in contrast to the middle-class school children (white or black)) exhibited external attribution.

Hypothesis II. Lower-class persons adjudge the occurrence of future events as more externally controlled, in comparison to middle-class persons.

Hypothesis $I I I$. Persons of the lower class envisage their future more pessimistically than persons of the middle class. This differential assessment of the future is especially expected in regard to the more distant future.

The lower-class person's perception of restriction upon his personal shaping of his future - the conviction that it is mainly external factors that determine the future and effect changes - may lead to apathy, resignated passivity (Popitz, Bahrdt, Jüres, and Kerting, 1967) as well as to withdrawal from social activity and from the confounding world of institutions, organizations and civil authorities (Oevermann, 1969). Instead, the primary relationships in the family and the circle of friends are strengthened within the lower class. This alignment of social interaction must also make itself evident in the concption of the future of lower-class persons.

Hypothesis $I V$. Persons of the lower class voice more hopes and fears pertaining to their private sphere of life than persons of the middle class, who on the other hand voice more hopes and fears pertaining to the public sphere.

\section{(2) Sex-specific roles}

Due to sex-specific child-raising and role expectations, stereotypes prevail as to the role distribution between man and woman (e.g., Myrdal and Klein, 1956; Lehr, 1968b, 1969). The man is the 'instrumental leader' of the family (Parsons, 1964), concentrating on the domain of professional and public life; whereas the woman is banned to her 'proper domain' of household and child-raising (Myrdal and Klein, 1956). Accordingly, the professional career with its implications for economic and political affairs takes on a central position in the man's autobiography, while women, also those with a profession, put the problems and events of their personal lives in the centre of their life portrayals (Lehr, 1968b, 1969). The reason for the differential emphasis upon various spheres of life is partly to be looked for in the fact that women's plans of life (also in the professional sphere) are determined relatively early by events and expectations in their personal lives, and for example, the aspirations for a good professional education are often given up in favour of an early marriage (Myrdal and Klein, 1956; and Lessing, 1968).

Hypothesis $V$. Women orient their evaluation of their psychological future more often to events in their personal lives than men do (greater number of events and longer extension of $\mathrm{FO}$ with regard to these events). Men, in contrast, include more professional and public events in their $\mathrm{FO}$ and extend their perspective in this area farther than women. 
Because in general sex-specific behavioural differences diminish in proportion to a rise in social class, this last hypothesis is valid above all in the lower class (Grauer, 1972a).

We expect sex-specific differences in optimism-pessimism, based upon the special situation of the 35 to 45 year-old women questioned here: they are confronted with changes in the family and the problems which begin with menopause (which is at least relevant for them in terms of their anticipation of it) and they have to come to terms with that, too, in their FO.

In a study which was mainly concerned with this problem area, Lehr (1968a) found that the fifth decade of life for a woman is characterized by a second crisis point (the first being in puberty). For the most part the children have finished their school and occupational education, and break ties with their paternal family; the parents or the woman's parents-in-law often demand care and help of their daughter (-in-law). Thus, Lehr (1968a) speaks of problems of role-overlapping which can be the source of many crises and conflicts between marriage partners. Added to that are the decisive biological changes which exercise a lasting influence upon the woman's psychological situation.

Hypothesis VI. Women have a more pessimistic attitude toward the future, especially in the family sector, than men of the same age.

\section{METHOD}

\section{Sample}

A sample of 125 employed men and women between the ages of 35 and 45 was drawn at random, from a population of adults who agreed to participate in the study after public invitation in the newspaper. The subjects had either a diploma after 8 years of school (lower educational level) or a high-school diploma or college degree (higher educational level). In addition, occupation and income were examined as measures of status.

Two independent judges classified each subject according to its occupational status as either middle or lower class. They used a categorization scheme which was developed from Kleining and Moore's (1968) data, and their results coincided in 89.3 per cent of the cases. From these 112 subjects 25 were selected at random for each of the four combinations of the independent variables. Thus 100 subjects were questioned. More than 72 per cent of the subjects were between 39 and 41 years old. Therefore it could be assumed that age-specific differences were largely precluded.

\section{Design}

The independent variables were 'sex' (factor A) and 'class' (factor B) (each factor with two levels), with 25 subjects per cell. In the analysis of the dependent variable optimism pessimism there was a further independent variable included: the point in time to which the assessment of future is directed (factor $\mathrm{C}$ ). This factor too, has two subdivisions ( $c_{1}=$ in 5 years; $c_{2}=$ in 20 years). 


\section{Experimental activities and methods of measurement}

The dependent variables were investigated through a questionnaire which the subjects were asked to complete ( 3 to 5 subjects per session). The variables were measured in detail as follows.

\section{Density}

On the first page of the questionnaire the subject had to name his hopes for the future and on the second page his fears ('What are your hopes [fears] for the future?'). The time limit was ten minutes in each case. (The results of a pilot study showed that in none of the four subject groups were more than $7 \mathrm{~min}$ necessary to answer the questions.)

These raw data were categorized by two independent raters who used Cantril's (1965) scheme (adapted and actualized for the German situation). The raters agreed in 85 per cent of the cases. The non-agreement cases constitute a residual category which was omitted from analysis. The original 23 categories of Cantril's questionnaire were reduced to three major catgories in the private sector (family, occupation, personal development) and three in the public sector (economy, politics, environment). The proportion of cited events which fell in these six categories in relation to the total number of cited events was calculated for each subject. To carry out the analysis of variance, these values were transformed with arc $\sin \sqrt{ } x$.

\section{Internal versus external control.}

Next, each subject indicated for each of his cited hopes and fears whether its fulfillment depended more on himself (or herself) or on outside factors (luck, chance, etc.). For this classification he was provided with four verbally labelled answer categories $(a=$ depends on me only, $\ldots, d=$ depends on chance and external factors).

The proportion of events judged as self-determined were calculated for the total private and public sectors. These scores were also transformed by arc $\sin \sqrt{x}$ to carry out the analysis of variance.

\section{Extension}

On the next page of the questionnaire each subject was asked to give his prospective age at the time of occurrence of each event (hope/fear).

To obtain an index of extension, we identified the hope or fear for which the subject indicated the most distant time of occurrence. For this hope or fear, the difference between the subject's age and his expected age at occurrence was calculated in each of the six categories, to yield the index of extension. Since these scores were not normally distributed, they were transformed with $\log x$ to permit an analysis of variance.

\section{Optimism-pessimism}

On the two last pages of the questionnaire the subject was presented with 10 items of the public domain (e.g., 'Crime in West Germany') and 10 items of the private domain (e.g., 'My financial situation'). These items were based on the most frequently cited concerns mentioned by subjects in surveys carried out by Lamm (1969) and Trommsdorff (1971) of students at the University of Mannheim. The subject's task 
was to assess, for each of the 20 items, his present situation, his situation in 5 years, and his situation in 20 years. This was to be done on an eleven-point-scale patterned after Cantril's (1965) 'aspiration ladder'. Its positive extreme represented the 'best conceivable situation', its negative extreme the 'worst conceivable situation'.

The difference between the evaluation 'in 5 years' (or 'in 20 years') and 'at present' was then calculated (positive difference = optimism; negative difference $=$ pessimism). The 20 items were condensed into three private categories - family ( 3 items), occupation ( 3 items), personal development ( 4 items) - and three public categories economics ( 1 item), politics ( 8 items) and environment ( 1 item). (These categories were designed to correspond to the six main categories of the density and extension variables.) In each of these categories the mean difference score (if more than I item) was then calculated and utilized as the score. The distribution of these data was normal so that an analysis of variance $(2 \times 2 \times 2)$ could be performed.

\section{RESULTS}

Tables 1 and 2 contain the means and standard deviations for the dependent variables and the significant results of the analyses of variance. In the case of significant interaction effects, simple effects were calculated (Winer, 1962, p. 174 and p. 340). The degrees of freedom for all listed $F$ values are 1 and 96 in all cases.

\section{Effects of social class}

\section{Density}

As Table 1 shows, there was no difference in number of events or type of events which were included in FO. This means that there were no more public (and also no more private) events expected by middle-class persons than by lower-class persons; accordingly, hypothesis IV had to be rejected.

\section{Extension}

Hypothesis I could be maintained because the middle-class members showed generally, in the private sector $(p<.05$ as well as in the public sector $(p<.001)$, a more extended FO than persons of the lower class.

\section{Internal vs. external control}

As expected, middle-class subjects, as compared to lower-class subjects, were more apt to believe that they could influence future events by means of their own intervention (hypothesis II): they designated more events as self-determined than lower-class persons $(p<.05)$. These differences are particularly marked with regard to hopes/fears in the public area $(p<.001)$.

\section{Optimism-pessimism}

Hypothesis III could be confirmed in the private area $(p<.05)$ and in the public area $(p<.005)$ as well as in the sub-areas of occupation $(p<.005)$, personal development $(p<.005)$ and environment $(p<.005)$. Middle-class persons evaluated the distant 


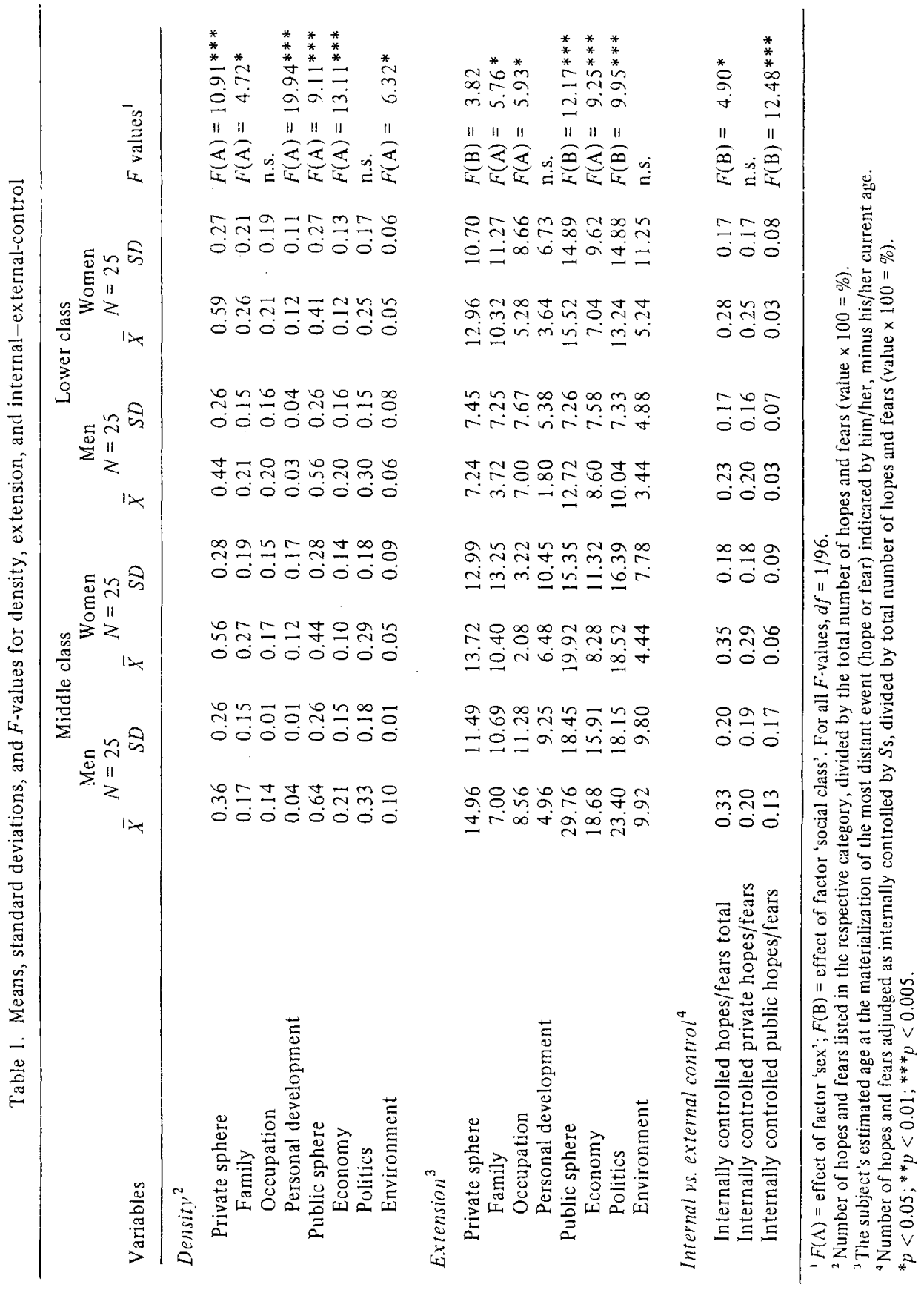




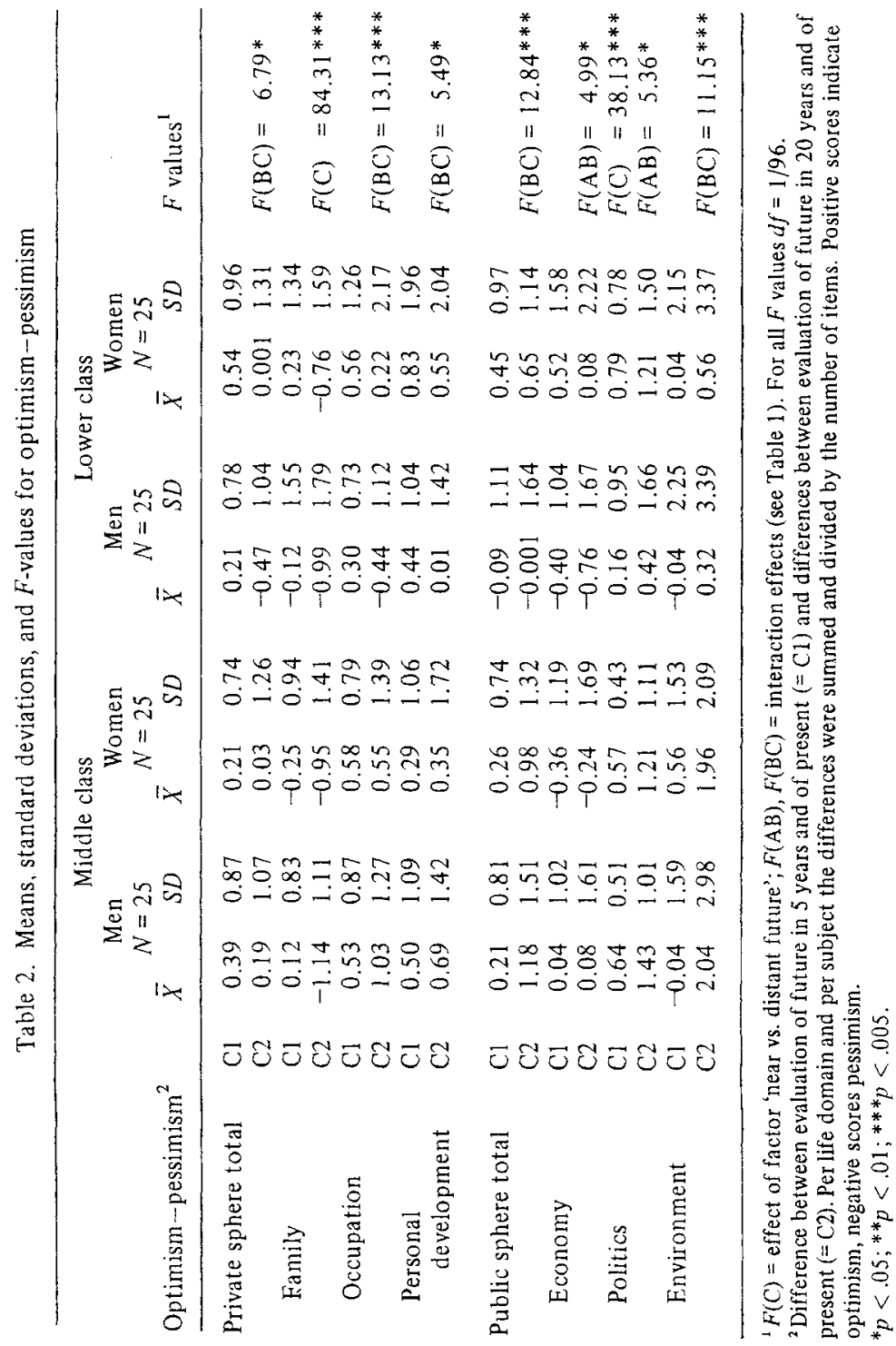


future in these areas more optimistically than persons of the lower class. In the political category the same tendency could be found, though the difference was only marginally significant $(p<.06)$.

Only in the private area $(F=44.93 ; p<.005)$ and the sub-area of occupation $(F=6.00 ; p<.05)$ did persons of the lower class evaluate the distant future less optimistically than the near future (simple effects).

It is true that in the categories of economy and family the mean difference indicated a substantiaton of the hypothesis; however, the difference was not significant in the first case, and in the second case the middle-class subjects also evaluated the distant future more pessimistically.

It should also be mentioned that the correlation between optimism and extension were not significant.

\section{Effects of sex}

\section{Density}

Men of both classes listed more public events than women $(p<.05)$ while the latter were more occupied with private events $(p<.005)$. Within the private sphere the women-independent of class level-were particularly concerned with future developments in the family: they voiced more hopes and fears in this category than men $(p<.05)$. These results were predicted by hypothesis $\mathrm{V}$. However, this hypothesis has to be partially restricted since the expected sex-specific differences concerning occupational (and political) events did not materialize.

\section{Extension}

The expected sex difference was found when partialling the private sphere into subcategories: in the family sector the women manifested a more extended future orientation $(p<.05)$ while in the economic area the reverse relation was found $(p<.05)$.

\section{Optimism-pessimism}

Within the area of the family the more distant future was evaluated more pessimistically than the near future by all subjects, independent of $\operatorname{sex}(p<.005)$. Hypothesis VI had to be rejected.

However, some unexpected interactions were found between sex and education. In the economic area the lower-class women anticipated a more positive future in comparison with lower-class men, while middle-class women and men gave relatively pessimistic judgments $(p<.05)$. Similarly, lower-class women proved to be strongly optimistic in relation to political development while lower-class men saw the future in that domain with more pessimism than middle-class men $(p<.05)$.

\section{DISCUSSION}

\section{Issue of a general FO}

One central (though not explicit) supposition upon which the previous FO research was based is that FO is always of the same structure, no matter to which area of life it is 
directed. For this reason, the FO of the subject in each of the respective studies was seldom specified in definite categories. The present results suggest that this practice may have been the source of contradictory findings in those previous studies. For example, women have a longer FO in the personal sphere and men in the occupational sphere. The supposition suggests itself that the results of LeShan (1957) and Ellis et al. (1955) and other authors would lose their contradictory character if the content variation of $\mathrm{FO}$ were considered.

Our results show that FO is intra-individually varied. Hence, the application of projective techniques (for example, story completion or TAT), which have been very popular in $F O$ research, becomes problematic because the respective data analyses do not do justice to any domain-specific FO variation in relation to extension, density and optimism-pessimism.?

\section{The influence of social status on $\mathrm{FO}$}

Except for the results concerning density ${ }^{8}$ the expected effects of social status on FO were found: lower-class persons envision their future (in all spheres) as controlled largely by external forces. It is perhaps because of the uncertainty going along with their beliefs in an externally controlled future that they do not make the attempt, as middle-class persons do, to structure their future as far ahead as possible. They hold themselves much more to relatively short-termed courses of events which they are able to understand. Correspondingly, they face the distant future more pessimistically than the near future.

In contrast, middle-class persons see a considerably greater chance for themselves to influence and control success patterns in the private or public sphere than do lowerclass persons. The future is presumably easier for them to comprehend. They include temporally distant events in their perspective and probably, because of that, have greater possibilities of adjusting their present behaviour to future developments and also of formulating more elaborate plans of behaviour to realize their goals. Whether or not goal-adequate behaviour is manifested to a greater extent by middle-class persons than by lower-class persons will have to be tested in further studies.

The belief of middle-class persons (relative to lower-class persons) that they can influence future developments has an analogy in their greater optimism. An indirect affirmation of the hypothesis that optimism and extension of FO are correlated can be seen in the finding that persons with higher education see the distant future (which would correspond with an extended FO) more optimistically than they see the close future, whereas persons with lower educational level see the distant future much more pessimistically than the close future.

The present study does not provide data that would permit one to explain the class differences in FO obtained here. Thus, the following two lines of interpretation are speculative and can only provide suggestions for research.

\footnotetext{
${ }^{7}$ A correlation between extension and optimism could not be reliably established in any of the four subject groups. Possibly the reasons were methodological, in that the 20 items used to measure optimism do not constitute identical categories relative to the categories imposed on the self-named hopes/fears. In a more thorough investigation of this relationship, the variables of extension and optimism-pessimism would, of course, have to be measured on exactly the same stimulus material (items).

${ }^{8}$ The collection of data took place during the election campaign for the Bundestag 1972, at a time when public events were of great interest for all groups in the population. This is probably the reason why the two educational classes did not show the predicted difference in the number of 'public' hopes and fears (hypothesis IV).
} 
For one thing, it should be examined whether any class-related differences in socialization practices lead to differences in FO. Thus it is conceivable that a mode of childrearing stressing (relative to one that is not stressing) independence and achievement - as is practiced in the middle class (Rosen, 1956; Neidhardt, 1968) leads to a more internal-oriented FO and one that is more extended and optimistic.

A second line of explanation is related to the one just indicated. The restriction of opportunities for experience and success characterizing the lower class causes (or even represents) social deprivation. (We will leave aside here the question of whether this deprivation is subjectively perceived or only objectively given.) Now the formation of FO involves the processing of past and present experiences and the relating of these to (imagined) future givens. If such domains of experience are limited by socio-economic restrictions (e.g., reference groups, financial and ecological resources), then a person's FO can, realistically, not overcome these socially mediated restrictions. Hence the FO of a lower-class person, relative to that of a middle-class person, will be less structured in various domains.

It should be emphasized that the crude dichotomous categorization of a population into lower and middle class, used in the present study, by no means provides an optimal social classification. For one thing, the cutting points between lower and middle class are problematic. For another thing, with such a crude dichotomization, the variance within the groups becomes so large as to preclude pertinent characterizations of these groups. Finally, such a dichotomization also may involve the danger of fixing existing stereotypes (e.g., about the 'lower class'), which are exactly based on such simplifying, dichotomous classifications.

While being thus aware of the imperfectness and danger of a dichotomous classification, we still see it as a first and preliminary step on the road to detecting and explaining differences in FO associated with socio-economic attributes.

In sum, to produce empirical evidence about the causes of the class-related differences found in our study, we would have to collect new, additional data. Thus, we can only speculate that the different socialization experience and different degree of susceptibility to becoming psychologically and/or socially deprived constitute some factors which stand behind the class-related variations of FO uncovered in this study.

\section{Influence of sex roles on FO}

The differences between females and males also seem amenable to an explanatory approach giving preeminence to socialization experiences, particularly in the way this is done by social-learning theory (cf. Ahammer, 1973; and Maccoby and Jacklin, 1974).

The present findings confirm the existence of the traditional role division of family and job spheres for women and men. According to this evidence, a higher level of education and employment of a woman does not necessarily mean better chances for her emancipation or even a reduction of traditional role differentiation: the expected interactional effect between status and sex was not found. Instead, the main effects of the factor 'sex' appeared in those spheres of life in which sex-specific differences for each respective role are traditional: women have more hopes and fears in the private sphere than men, and reversely, men refer more often to public events than women in envisioning their future.

By observation of the results for the component 'extension', however, it was found that even though women and men have the same number of occupationally relevant 
concerns (hopes and fears), these concerns lie more in the immediate future for women, while men have a more long-term FO. The longer-term FO for women, relative to men, in the family sphere, corresponds to the traditional role conception.

If 'extension' is seen as relevant to planning, one may conclude that women feel more responsible for plans in the family sphere whereas men are responsible for occupational plans. This statement is valid for both classes investigated here.

Contrary to expectations, there was no sex-specific difference in the family domain for the variable optimism-pessimism: men as well as women evaluated the distant future more pessimistically than the near future. Apparently men feel the pressure of coming changes in the family. Added to this is probably the anticipation of health crises, which also have an adverse effect on family life, coloring the FO pessimistically.

In order to interpret the relatively complicated interaction between sex and social status for optimism-pessimism in regard to economics and politics, simple effects were calculated. It was found that in the domains 'economics' and of 'politics' only the values of lower-class women and men were significantly different $\left(F_{S}=5.02 ; p<.05\right.$; $F_{S}=7.55 ; p<.01$, respectively): lower-class women were more optimistic than lower-class men.

Surprising in these findings is the relatively optimistic attitude of the lower-class women. Since women are less concerned with events of public life (compare the results on density), one must suppose that they are also less informed about actual and potential developments in this sphere and thus are unsure in their evaluation of these developments. One possibility of reducing this uncertainty may be in the denial of undesirable future developments, thus focussing primarily on positive images of one's future in making judgments of optimism-pessimism. In this sense the relatively strong optimism of the lower-class women could be considered as a defensive future orientation.

Why middle-class women do not react similarly remains as open question. Possibly, these women, because of their higher educational level are less prone to such unrealistic rationalization mechanisms. However, this is not to say that a pessimistic FO is always an expression of realistic evaluation.

\section{REFERENCES}

Ahammer, I. M. (1973). Social learning theory as a framework for the study of adult personality development. In: Baltes, P. B. and Schaie, K. W. Life-span developmental psychology. New York: Academic Press.

Allen, V. L. (1970). The psychology of poverty: problems and prospects. In: Allen, V. L. (Ed.), Psychological factors in poverty. Chicago: Markham.

Barabasz, A. F. (1970). Temporal orientation and academic achievement in college. Journal of Social Psychology, 80: 231-232.

Barndt, R. J., and Johnson, D. M. (1955). Time orientation in delinquents. Journal of Abnormal and Social Psychology, 51: 343-345.

Battle, E. S., and Rotter, J. B. (1963). Children's feelings of personal control as related to social class and ethnic groups. Journal of Personality, 31: 482-490.

Bergius, R. (1957). Formen des Zukunftserlebens. München: Barth.

Bernstein, B. (1959). Sozio-kulturelle Determinanten des Lernens. Mit besonderer Berücksichtigung der Rolle der Sprache. Kölner Zeitschrift für Soziologie und Sozialpsychologie, Sonderheft, 4: 52-79. 
Brim, O. G. Jr., and Forer, R. A. (1956). A note on the relation of values and social structure to life planning. Sociometry, 19: 54-60.

Cantril, H. (1965). The Pattern of Human Concerns. New Brunswick, N.J.: Rutgers University Press.

Cohen, A. K. (1955). Delinquent Boys. New York: Free Press.

Cottle, T. J., and Klineberg, St. L. (1974). The Present of Things Future: Exploration of Time in Human Experience. New York: The Free Press.

Daheim, H. (19702). Der Beruf in der modernen Gesellschaft. Köln: Kiepenheuer \& Witsch.

Doob, L. W. (1971). Patterning of time. New Haven: Yale University Press.

Ellis, L. M., Ellis, R., Mandel, E. D., Schaeffer, M. S., Sommer, G., and Sommer, G. (1955). Time orientation and social class: An experimental supplement. Journal of Abnormal and Social Psychology, 51: 146-147.

Ewert, O. (1970). ${ }^{2}$ Erziehungsstile in ihrer Abhängigkeit von soziokulturellen Normen. In: Herrman, T. (Ed.), Psychologie der Erziehungsstile. Göttingen: Hogrefe.

Fraisse, P. (1957). Psychologie du Temps. Paris: Presses Universitaires.

Frank, L. K. (1939). Time perspectives. Journal of Social Philosophy, 4: 293-312.

Gore, P. M., and Rotter, J. B. (1963). A personality correlate of social action. Journal of Personality, 31: 58-64.

Grauer, G. (1972a). Leitbilder und Erziehungspraktiken. In: b:e Redaktion (Eds.), Familienerziehung, Sozialschicht und Schulerfolg. Weinheim: Beltz, 37-58.

Grauer, G. (1972b). Die Entwicklung des Leistungsstrebens. In b:e Redaktion (Eds.), Familienerziehung, Sozialschicht und Schulerfolg. Weinheim: Beltz, 59-82.

Graves, T. D. (1968). Time perspective and the deferred qualification pattern in a tri-ethnic community. Unpublished doctoral dissertation, University of Pennsylvania, 1962. Cited in: Lessing, E. E. Demographic, developmental and personal correlates of length of future time perspective. Journal of Personality, 36: 183-201.

Grimm, S. (1966). Die Bildungschancen der Arbeiter, München: Barth.

Heckhausen, H. (1963). Hoffnung und Furcht in der Leistungsmotivation. Meisenheim am Glan: Hain.

Heckhausen, H. (1967). The Anatomy of Achievement Motivation. New York: Academic Press.

Hess, R. D., and Shipman, V. (1965) Early experience and the socialization of cognitive models in children. Child Development. 36: 869-886.

Jessor, R., Graves, Th.D., Hanson, R. C., and Jessor, S. L. (1968). Society, Personality, and Deviant Behavior. New York: Holt, Rinehart \& Winston.

Judson, A. J., and Tuttle, C. E. (1966). Time perspective and social class. Perceptual and Motor Skills, 23: 1074.

Kasakos, G. (1971). Zeitperspektive, Planungsverhalten und Sozialisation: Überblick über internationale Forschungsergebnisse. München: Juventa.

Kastenbaum, R. (1961). The dimensions of future time perspective: An experimental analysis. Journal of General Psychology, 65: 203-218.

Kleining, G., and Moore, H. (1968). Soziale Selbsteinstufung (SSE). Ein Instrument zur Messung sozialer Schichten. Kölner Zeitschrift für Soziologie und Sozialpsychologie, 20: 502-552.

Klineberg, St. L. (1967). Changes in outlook on the future between childhood and adolescence. Journal of Personality and Social Psychology, 7: 185-193.

Klineberg, St. L. (1968). Future time perspective and the preference for delayed reward. Journal of Personality and Social Psychology, 8: 253-257.

Knupfer, G. (1953). Portrait of the underdog. In: Bendix, R. and Lipset, S. M. (Eds.), Class, Status, and Power. New York: The Free Press of Glencoe, pp. 255-263.

Lamm, H. (1969). Untersuchungen über Zukunftsvorstellungen. Unpublished data. Universität Mannheim, SFB 24.

Lehr, U. (1968a). Zur Problematik des Menschen im reiferen Erwachsenenalter. - Eine sozialpsycholgische Interpretation der "Wechseljahre". In: Thomae, H. and Lehr, U. (Eds.), Altern, Probleme und Tatsachen. Frankfurt/M.: Akademische Verlagsgesellschaft, pp. 227-234.

Lehr, U. (1968b). Veränderungen der Daseinsthematik der Frau im Erwachsenenalter. In: Thomae, H. and Lehr, U. (Eds.), Altern, Probleme und Tatsachen. Frankfurt/M.: Akademische Verlagsgesellschaft, pp. 469-504. 
Lehr, U. (1969). Die Frau im Beruf. Frankfurt/M.: Athenäum.

Lenski, G. E. (1966). Power and Privilege: A Theory of Social Stratification. New York: McGraw-Hill.

LeShan, L. L. (1952). Time orientation and social class. Journal of Abnormal and Social Psychology, 47: 589-592.

Lessing, E. E. (1968). Demographic, developmental, and personality correlates of length of future time perspective (FTP). Journal of Personality, 36: 183-201.

Lessing, E. E. (1971). Comparative extension of personal and social-political future time perspective. Perceptual and Motor Skills, 33: 415-422.

Lewin, K. (1948). Time perspective and morale. In: Lewin, K. (Ed.), Resolving Social Conflicts. New York: Harper, pp. 103-124.

Lewin, K. (1951). Field Theory in Social Science. New York: Harper.

Maccoby, E. E., and Jacklin, C. N. (1974). The Psychology of Sex Differences. Stanford, Calif: Stanford University Press.

Miller, S. M., Riesman, F., and Seagull, A. A. (1965). Poverty and self-indulgence: A critique of the non-deferred gratification pattern. In: Forman, L. A., Kornbluth, J. L., and Haber, A (Eds.), Poverty in America. Ann Arbor.

Mischel, W. (1974). Processes in delay of gratification. In: Berkowitz, L. (Ed.), Advances in Experimental Social Psychology. Vol. 7, New York: Academic Press.

Mönks, F. J. (1967). Sammelreferat: Zeitperspektive als psychologische Variable. Archiv für die gesamte Psychologie, 119, 131-161.

Mollenhauer, K. (1969). Sozialisation und Schulerfolg. In: Roth, H. (Ed.), Begabung und Lernen. Stuttgart: Klett, pp. 269-296.

Myrdal, A., and Klein, V. (1956). Women's Two Roles: Home and Work. London: Routledge \& Kegan.

Neidhardt, F. (1967). Schichtbedingte Elterneinflüsse im Erziehungs-und Bildungsproze $\beta$ der heranwachsenden Generation. Bundesministerium für Familie und Jugend (Ed.), Bad Godesberg.

Neidhardt, F. (1968). Schichtspezifische Elterneinflüsse im Sozialisationsprozeß. In: Wurzbacher G. (Ed.), Die Familie als Sozialisationsfaktor. Stuttgart: Enke, pp. 174-200.

Oevermann, U. (1969). Schichtenspezifische Formen des Sprachverhaltens und ihr Einfluß auf die kognitiven Prozesse. In: Roth H. (Ed.), Begabung und Lernen. Stuttgart: Klett, pp. 297-355.

Oevermann, U. (19722). Sprache und soziale Herkunft. Frankfurt/M.: Suhrkamp, $1972^{2}$.

Ornauer, H., Wiberg, H., Sicinsky, A., and Galtung, J. (Eds.), (1974), Images of the World in the year 2000: A Ten Nation Comparative Study. The Hague: Mouton.

Parsons, T. (1964). Das Inzesttabu in seiner Beziehung zur Sozialstruktur und zur Sozialisierung des Kindes. In: Parsons, T. (Ed.), Soziologische Theorie Neuwied: Luchterhand, pp. 109-135.

Platt, J. J., Eisenmann, R., Delisser, O., and Darbes, A. (1971). Temporal perspective as a personality dimension in college students: A re-evaluation. Perceptual and Motor Skills, 33 : $103-109$.

Popitz, H., Bahrdt, H. P., Jüres, E. A., and Kesting, H. (19673) Das Gesellschaftsbild des Arbeiters. Tübingen: Mohr (Siebeck).

Rosen, B. C. (1956). The achievement syndrome: A psychocultural dimension of social stratification. American Sociological Review, 21: 203-211.

Ruiz, R. A., Reivich, R. S., and Krauss, H. H. (1967). Tests of temporal perspective: Do they measure the same construct? Psychological Reports, 21: 849-852.

Stein, K. B., Sarbin, Th.R., and Kulik, J. A. (1968). Future time perspective: Its relation to the socialization process and the delinquent role. Journal of Consulting and Clinical Psychology, 32: $257-264$.

Teahan, J. E. (1958). Future time perspective, optimism, and academic achievement. Journal of Abnormal and Social Psychology, 57: 379-380.

Tolor, A., Brannigan, G. G., and Murphy, V. M. (1970). Psychological distance, future time perspective, and internal-external expectancy. Journal of Projective Techniques and Personality Assessment, 34: 283-294.

Trommsdorff, G. (1971). Untersuchungen über Zukunftsvorstellungen. Unpublished data. Universität Mannheim, SFB 24. 
Trommsdorff, G., and Lamm, H. (1975). An analysis of future orientation and some of its social determinants. In: Fraser, J. T. and Lawrence, N. (Eds.), The Study of Time II. Heidelberg/New York: Springer.

Vincent, J. W. (1965). An investigation of constricted and extended temporal perspectives. Unpublished master's thesis, University of Oregon.

Wallace, M. (1956). Future time perspective in schizophrenia. Journal of Abnormal and Social Psychology, 52, 240-245.

Winer, B. J. (1962). Statistical Principles in Experimental Design. New York: McGraw-Hill.

Winnubst, J. (1974). Tijdsperspektief: Overzicht - Kritiek - Bibliografie. Nederlands Tijdschrifi voor de Psychologie, 28: 581-617.

Witkin, H. A., Dyk, R. B., Faterson, H., Goodenough, D. R., and Karp, S. A. (1962). Psychological Differentiation: Studies of Development. New York: Wiley.

Wurzbacher, G. (1966). Beruf und Schule als Faktoren sozio-kultureller und personaler Strukturierung und Veränderung. In: Scharmann, T. (Ed.), Schule und Beruf als Sozialisationsfaktoren. Stuttgart: Enke, pp. 74-112.

\section{RÉSUME}

Cette recherche étudie l'influence des rôles sexuels et du statut social sur les perspective d'avenir considérées en plusieurs catégories (domaines de vie) sous les dimensions de densité (nombre de craintes et d'espoirs cités par le sujet), d'extension et d'optimisme-pessimisme, ainsi qu par rapport à une dimension contrôle interne-externe. Les sujets étaient 100 salariés, hommes et femmes, de classe moyenne et basse. On a trouvé que les hommes, comparés aux femmes, expriment plus d'espoirs et de craintes dans le domaine public (économie, politique, environnement) et moins dans le domaine privé (famille, emploi, développement personnel). Les hommes avaient des perspectives d'avenir plus étendues dans le domaine professionnel et économique, les femmes dans le domaine privé. Ces résultats vont donc à l'encontre de conceptions présentes dans d'autres études qui considèrent les perspectives d'avenir comme relevant d'une attitude générale, consistante à travers les différents domaines de la vie. Les membres des classes moyennes (par rapport aux classes basses) manifestent des perspectives d'avenir plus étendues, plus optimistes et croient davantage que la réalisation de leurs espoirs et craintes dépend d'eux-mêmes.

\section{ZUSAMMENFASSUNG}

Um Hypothesen zum Einfluß der Geschlechtsrolle und der Schichtzugehörigkeit auf die Zukunftsperspektive ( $\mathrm{ZP}$ ) zu überprüfen, wurde ZP in verschiedene Kategorien (Lebensbereichen) gemessen und zwar auf den Dimensionen 'Dichte' (Anzahl der von Vpn genannten Hoffnungen und Befürchtungen), 'Ausdehnung' und 'Optimismus-Pessimismus'. Außerdem wurde die Variable 'internale vs. externale Kontrolle' erhoben (operationalisiert durch die Beurteilung der $V_{p n}$, inwieweit der Eintritt ihrer $H$ offnungen und Befürchtungen mehr von ihnen selbst oder mehr von externen Faktoren abhängig ist). Untersucht wurden je 25 berufstätige Männer und Frauen aus der Unter- und der Mittelschicht. Es zeigten sich unterschiedliche Effekte der unabhängigen Variablen 'Geschlecht' und 'Schicht' in den verschiedenen Lebensbereichen. Im Vergleich zu Frauen nannten Männer mehr den öffentlichen Bereich betreffende Hoffnungen/Befürchtungen (Wirtschaft, Politik, Umwelt) und weniger den privaten Bereich betreffende Hoffnungen/Befürchtungen (Familie, Beruf, Persönlichkeitsentfaltung). Männer hatten eine ausgedehntere ZP im beruflichen und wirtschaftlichen Bereich, Frauen hingegen im familiären Bereich. (Diese Ergebnisse widersprechen 
der These einer über alle Lebensbereiche generalisierten $Z P$, die für verschiedene Bereiche gleiche Zukunftsvorstellungen vorhersagen würde.) Die Hypothese, daß die geschlechtsbedingten Unterschiede auf die Unterschicht beschränkt bleiben, konnte nicht bestätigt werden. 